\title{
Cermet Composite Thermal Spray Coatings for Erosion and Corrosion Protection in Combustion Environments of Advanced Coal-Fired Boilers
}

Semiannual Technical Report Prepared for U.S. Department of
Energy

Project Period: 8/14/96-1/14/97

by

B. F. Levin, J.N. DuPont and A.R. Marder

February 1, 1997

Grant No. DE-FG22-95PC95211

Energy Research Center
117 ATLSS Drive
Lehigh University
Bethlehem, PA 18015

DOE Project Officer: Sean I. Plasynski

Administered by: Cynthia Y. Mitchell 


\section{$\underline{\text { Disclamer }}$}

This report was prepared as an account of work sponsored by an agency of the United States Government. Neither the United States Government nor any agency thereof, nor any of their employees, makes any warranty, express or implied, or assumes any legal liability or responsibility for the accuracy, completeness, or usefulness of any information, apparatus, product, or process disclosed, or represents that its use would not infringe privately owned rights. Reference herein to any specific commercial product, process, or service by trade name, trademark, manufacturer, or otherwise does not necessarily constitute or imply endorsement, recommendation, or favoring by the United States Government or agency thereof. The views and opinions of authors expressed herein do not necessarily state or reflect those of the United States Government or any agency thereof. 


\section{EXECUTIVE SUMMARY}

Research is presently being conducted to determine the optimum ceramic/metal combination in thermally sprayed metal matrix composite coatings for erosion and corrosion resistance in new coal-fired boilers. The research will be accomplished by producing model cermet composites using powder metallurgy and electrodeposition methods in which the effect of ceramic/metal combination for the erosion and corrosion resistance will be determined. These results will provide the basis for determining the optimum hard phase constituent size and volume percent in thermal spray coatings. Thermal spray coatings will be applied by our industrial sponsor and tested in our erosion and corrosion laboratories.

In the first six months of this project, bulk powder processed $\mathrm{Ni}-\mathrm{Al}_{2} \mathrm{O}_{3}$ composites were produced at Idaho National Engineering Laboratory. The results of microstructural characterization of these alloys were presented in the first semiannual report [1]. The composite samples contained $0,21,27,37$, and 45 volume percent $\mathrm{Al}_{2} \mathrm{O}_{3}$ with an average particle size of 12 um. An increase in the volume fraction of alumina in the nickel matrix from 0 to $45 \%$ led to a significant increase in hardness of these composites.

During the second six months model $\mathrm{Ni}_{-} \mathrm{Al}_{2} \mathrm{O}_{3}$ cermet coatings with various volume fractions of alumina were produced. To deposit $\mathrm{Ni}-\mathrm{Al}_{2} \mathrm{O}_{3}$ coatings, an electrodeposition technique was developed and coatings with various volume fractions $(0-35 \%)$ of $\mathrm{Al}_{2} \mathrm{O}_{3}$ were produced. The experimental procedure and microstructural characterization of $\mathrm{Ni}_{-} \mathrm{Al}_{2} \mathrm{O}_{3}$ electrodeposited cermet coatings were presented in the last progress report [2]. The powder and electrodeposition processing of $\mathrm{Ni}-\mathrm{Al}_{2} \mathrm{O}_{3}$ composites provide the ability to produce a different volume fractions of the second phase without changing the composition of the matrix material. Therefore, the effect 
of hard second phase particle volume fraction and size on erosion resistance can be analyzed.

During the last six months, powder processed and electrodeposited composites were tested in the erosion simulator $\left(\mathrm{Al}_{2} \mathrm{O}_{3}\right.$ erodent, $40 \mathrm{~m} / \mathrm{s}$ velocity, and $90^{\circ}$ impact angle $)$ and their relative erosion resistances were determined. It was found that electrodeposited $\mathrm{Ni}-\mathrm{Al}_{2} \mathrm{O}_{3}$ composites containing small $\mathrm{Al}_{2} \mathrm{O}_{3}$ particles $(\approx 1 \mathrm{um})$ showed better erosion resistance than powder processed $\mathrm{Ni}-\mathrm{Al}_{2} \mathrm{O}_{3}$ composites containing large $\mathrm{Al}_{2} \mathrm{O}_{3}$ particles $(\approx 12 \mathrm{um})$. Also, an increase in the volume fraction of $\mathrm{Al}_{2} \mathrm{O}_{3}$ particles in powder processed alloys led to a decrease in erosion resistance. For both powder processed and electrodeposited $\mathrm{Ni}-\mathrm{Al}_{2} \mathrm{O}_{3}$ composites, addition of hard $\mathrm{Al}_{2} \mathrm{O}_{3}$ particles did not improve erosion resistance compared with pure nickel. The experimental procedure, results, and discussion of the erosion tests are presented in this progress report.

\section{INTRODUCTION}


Present coal-fired boiler environments remain hostile to the materials of choice since corrosion and erosion can be a serious problem in certain regions of the boiler. Recently, the Clean Air Act Amendment is requiring electric power plants to reduce $\mathrm{NO}_{\mathrm{x}}$ emissions to the environment. To reduce $\mathrm{NO}_{\mathrm{x}}$ emissions, new low $\mathrm{NO}_{\mathrm{x}}$ combustors are utilized which burn fuel with a substoichiometric amount of oxygen (i.e., low oxygen partial pressure). In these low $\mathrm{NO}_{\mathrm{x}}$ environments, $\mathrm{H}_{2} \mathrm{~S}$ gas is a major source of sulfur. Due to the sulfidation process, corrosion rates in reducing parts of boilers have increased significantly and existing boiler tube materials do not always provide adequate corrosion resistance. Combined attack due to corrosion and erosion is a concern because of the significantly increased operating costs which result in material failures.

One method to combat corrosion and erosion in coal-fired boilers is to apply coatings to the components subjected to aggressive environments. Thermal spray coatings, a cermet composite comprised of hard ceramic phases of oxide and/or carbide in a metal binder, have been used with some success as a solution to the corrosion and erosion problems in boilers. However, little is known on the effect of the volume fraction, size, and shape of the hard ceramic phase on the erosion and corrosion resistance of the thermally sprayed coatings. It is the objective of this research to investigate metal matrix composite (cermet) coatings in order to determine the optimum ceramic/metal combination that will give the best erosion and corrosion resistance in new advanced coal-fired boilers.

\section{EXPERIMENTAL PROCEDURE}


During the last six months electrodeposited and powder processed $\mathrm{Ni}-\mathrm{Al}_{2} \mathrm{O}_{3}$ composites with different volume fractions of $\mathrm{Al}_{2} \mathrm{O}_{3}$ particles (0-45\%) were tested in the erosion simulator. Because powder and electrodeposited alloys have different $\mathrm{Al}_{2} \mathrm{O}_{3}$ particle sizes with similar volume fractions, the effect of particle size and volume on erosion resistance of $\mathrm{Ni}-\mathrm{Al}_{2} \mathrm{O}_{3}$ composites can be analyzed. Microstructural characterization of $\mathrm{Ni}-\mathrm{Al}_{2} \mathrm{O}_{3}$ composites was presented in the previous progress reports [1,2].

A schematic diagram of the erosion tester used in this study is shown in Figure 1. The system is driven by an air compressor and the air is cleaned through a series of filters to remove any entrained water. The flow meter and pressure regulator control the amount of air that flow through the system and the air can be heated by two inline fluid heaters. The erosive particles are fed into the air stream with a screw feeder to ensure constant feed rates. The particles and air are accelerated and impinge upon the sample at any angle between $0^{\circ}$ and $90^{\circ}$. The particle velocity distribution prior to impact is directly measured with a Laser Doppler Velocometer (LDV).

The standard test conditions that were chosen for this study are listed in Table I. Five to seven different erosion exposure times (30min. intervals) were used in this study to adequately obtain the weight loss vs. time plot for each material, the slopes of which yield the steady state erosion rate. To quantify weight loss during the erosion experiments, the erosion specimens were ultrasonically cleaned in acetone and weighed before and after the erosion tests to the nearest 0.1 mg.

\section{RESULTS AND DISCUSSION}


Erosion weight loss versus time plots for powder processed and electrodeposited composites are shown in Figure $2 \mathrm{a}$ and $\mathrm{b}$. The steady state erosion rates for all alloys are presented in Table II. For the powder processed $\mathrm{Ni}-\mathrm{Al}_{2} \mathrm{O}_{3}$ alloys, the composite with the largest volume fraction of $\mathrm{Al}_{2} \mathrm{O}_{3}$ (45 vol. \%) showed the highest erosion rate, while pure Ni showed the lowest erosion rate. Similar results were observed for the electrodeposited $\mathrm{Ni}-\mathrm{Al}_{2} \mathrm{O}_{3}$ composites for which alloy with the largest $\mathrm{Al}_{2} \mathrm{O}_{3}$ content (39 vol.\%) had the highest erosion rate and pure Ni exhibited the lowest erosion rate.

The effect of volume fraction of $\mathrm{Al}_{2} \mathrm{O}_{3}$ particles on erosion resistance of the $\mathrm{Ni}-\mathrm{Al}_{2} \mathrm{O}_{3}$ composites is shown in Figure 3. It can be seen that an increase in $\mathrm{Al}_{2} \mathrm{O}_{3}$ content led to an increase in erosion rate of the composites. Also, electrodeposited $\mathrm{Ni}-\mathrm{Al}_{2} \mathrm{O}_{3}$ alloys exhibited better erosion resistance than powder processed Ni- $\mathrm{Al}_{2} \mathrm{O}_{3}$ alloys. Although both types of $\mathrm{Ni}-\mathrm{Al}_{2} \mathrm{O}_{3}$ composites contained approximately the same volume fraction of $\mathrm{Al}_{2} \mathrm{O}_{3}$ particles, the size of these particles is an order of magnitude smaller for the electrodeposits than for the powder alloys

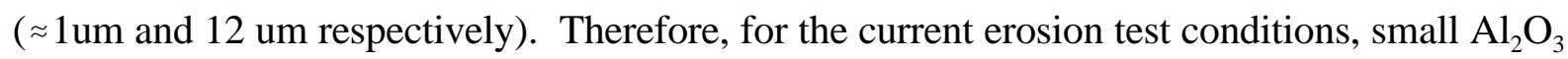
particles in a $\mathrm{Ni}$ matrix were more beneficial in terms of erosion resistance than large $\mathrm{Al}_{2} \mathrm{O}_{3}$ particles. Similar results were obtained by Lindsley [3] for the $\mathrm{Fe}_{-} \mathrm{Fe}_{3} \mathrm{C}$ alloy system in which composites with small carbide $\left(\mathrm{Fe}_{3} \mathrm{C}\right)$ particles were more erosion resistant than those with large particles. Typically, small particles are less likely to fracture during impact than large particles because the former contain fewer preexisting defects (i.e., cracks). Preexisting defects in brittle ceramic particles create stress concentrations and may cause rapid crack propagation and fracture during the impact. It is possible that the main cause of the weight loss in tested $\mathrm{Ni}-\mathrm{Al}_{2} \mathrm{O}_{3}$ is cracking and removal of brittle $\mathrm{Al}_{2} \mathrm{O}_{3}$ particles. Therefore, small particles can provide better 
erosion resistance than larger particles. However, neither size particles provided any benefit to erosion resistance of $\mathrm{Ni}-\mathrm{Al}_{2} \mathrm{O}_{3}$ alloys compared with pure $\mathrm{Ni}$. Also, cracking and removal of the $\mathrm{Al}_{2} \mathrm{O}_{3}$ particles may be responsible for an increase in erosion rate with an increase in volume fraction of $\mathrm{Al}_{2} \mathrm{O}_{3}$ as shown in Figure 3. The microstructural analysis of the tested alloys will be conducted to determine the extent of the $\mathrm{Al}_{2} \mathrm{O}_{3}$ particles fracture and subsequent erosion mechanism in $\mathrm{Ni}-\mathrm{Al}_{2} \mathrm{O}_{3}$ composites.

\section{CONCLUSIONS}

Based on the results of the erosion tests for the $\mathrm{Ni}-\mathrm{Al}_{2} \mathrm{O}_{3}$ powder processed and electrodeposited composite alloys the following can be concluded:

1. An increase in volume fraction of $\mathrm{Al}_{2} \mathrm{O}_{3}$ particles from 0 to $45 \mathrm{vol} . \%$ led to an increase in erosion rate of the composites. Pure Ni alloys showed the best erosion resistance.

2. For the current erosion test conditions, small $\mathrm{Al}_{2} \mathrm{O}_{3}$ particles in a $\mathrm{Ni}$ matrix (electrodeposited alloys, $\mathrm{Al}_{2} \mathrm{O}_{3}$ size $\approx 1 \mathrm{um}$ ) were more beneficial in terms of erosion resistance than large $\mathrm{Al}_{2} \mathrm{O}_{3}$ particles (powder alloys, $\mathrm{Al}_{2} \mathrm{O}_{3}$ size $\approx 12 \mathrm{um}$ ).

\section{PLANS FOR COMING YEAR:}

In the next six months, the microstructure of powder and electrodeposited cermet alloys after erosion will be analyzed using light optical and scanning electron microscopy techniques. Also, microhardness tests will be performed on all alloys to determine the extent of plastic deformation beneath the eroded surface. From these results we expect to determine the mechanism of erosion for the $\mathrm{Ni}-\mathrm{Al}_{2} \mathrm{O}_{3}$ metal-matrix composites. 


\section{REFERENCES}

1. B.F. Levin, J.N. DuPont, and A.R. Marder, Semiannual Progress Report Prepared for U.S. Department of Energy The Period July 1995 through January 1996, Lehigh University, Energy Reseacrh Center, Bethlehem, PA 18015.

2. B.F. Levin, J.N. DuPont, and A.R. Marder, Semiannual Progress Report Prepared for U.S. Department of Energy The Period February 1996 through July 1996, 96-500-09-31, Lehigh University, Energy Reseacrh Center, Bethlehem, PA 18015.

3. B.L. Lindsley, Ph.D Thesis, Department of Materials Science, Lehigh University, 1996.

Table I. Erosion tests conditions.

\begin{tabular}{|l|l|}
\hline Eroded Sample Planar Dimensions & $9 \mathrm{~mm} \times 9 \mathrm{~mm}$ \\
\hline Sample Temperature & $20^{\circ} \mathrm{C}$ \\
\hline
\end{tabular}




\begin{tabular}{|l|l|}
\hline Erodent Particle Velocity & $40 \mathrm{~m} / \mathrm{s} \pm 5 \mathrm{~m} / \mathrm{s}$ \\
\hline Erodent Particles Flux & $7.2 \mathrm{mg} /\left(\mathrm{mm}^{2} / \mathrm{sec}\right)$ \\
\hline Impingement Angle & $90^{\circ}$ \\
\hline Erodent & angular alumina $\left(\mathrm{Al}_{2} \mathrm{O}_{3}\right)$ \\
\hline Erodent Size Range & $355-425 \mu \mathrm{m}$ \\
\hline Average Diameter Of The Erodent & $380 \mu \mathrm{m}$ \\
\hline
\end{tabular}

Table II. Erosion rates for the $\mathrm{Ni}-\mathrm{Al}_{2} \mathrm{O}_{3}$ alloys tested.

\begin{tabular}{|l|c|}
\hline Alloy & Erosion Rate $(\mathbf{m g} / \mathbf{m i n}) \mathbf{x} \mathbf{1 0}^{\mathbf{2}}$ \\
\hline Ni powder processed & $8.5 \pm 0.1$ \\
Ni-21vol.\% $\mathrm{Al}_{2} \mathrm{O}_{3}$, powder processed & $11.2 \pm 0.1$ \\
$\mathrm{Ni}-27$ vol.\% $\mathrm{Al}_{2} \mathrm{O}_{3}$, powder processed & $11.9 \pm 0.1$ \\
$\mathrm{Ni}-37$ vol.\% $\mathrm{Al}_{2} \mathrm{O}_{3}$, powder processed & $16.3 \pm 0.6$ \\
$\mathrm{Ni}-45$ vol.\% $\mathrm{Al}_{2} \mathrm{O}_{3}$, powder processed & $17.1 \pm 0.3$ \\
$\mathrm{Ni}$ electrodeposited & $7.5 \pm 0.1$ \\
$\mathrm{Ni}-5$ vol.\% $\mathrm{Al}_{2} \mathrm{O}_{3}$, electrodeposited & $9.0 \pm 0.1$ \\
$\mathrm{Ni}-23$ vol.\% $\mathrm{Al}_{2} \mathrm{O}_{3}$, electrodeposited & $9.1 \pm 0.2$ \\
$\mathrm{Ni}-32$ vol.\% $\mathrm{Al}_{2} \mathrm{O}_{3}$, electrodeposited & $8.6 \pm 0.1$ \\
$\mathrm{Ni}-39$ vol.\% $\mathrm{Al}_{2} \mathrm{O}_{3}$, electrodeposited & $10.5 \pm 0.1$ \\
\hline
\end{tabular}


Figure 1. Schematic diagram of the erosion apparatus. 
Figure 2 a and b. Erosion kinetics for the powder processed (a) and electrodeposited (b) $\mathrm{Ni}-\mathrm{Al}_{2} \mathrm{O}_{3}$ composite alloys. 
Figure 3. Effect of volume fraction of $\mathrm{Al}_{2} \mathrm{O}_{3}$ particles on erosion resistance of $\mathrm{Ni}-\mathrm{Al}_{2} \mathrm{O}_{3}$ composite alloys. 


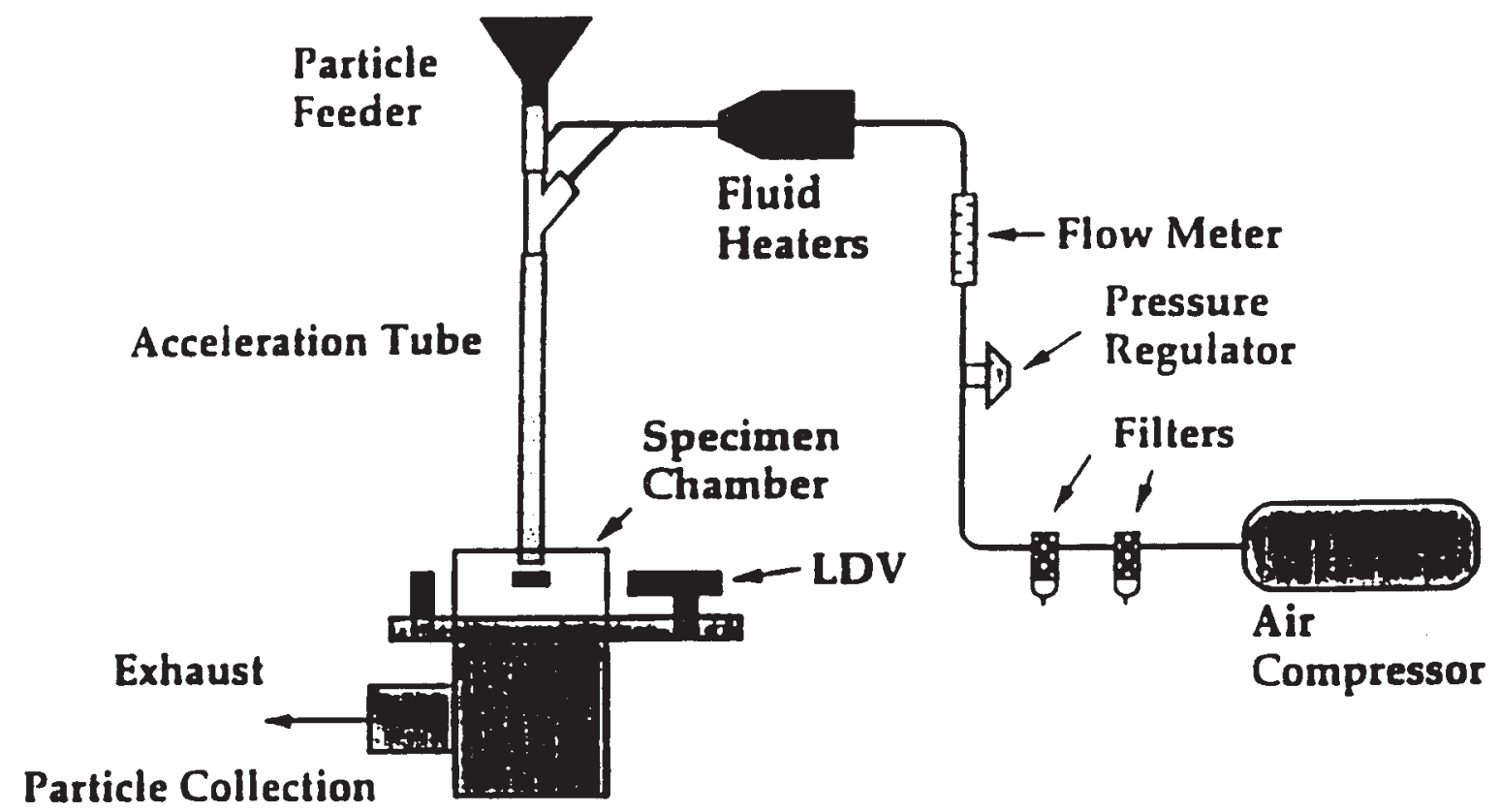

Figure 1. Schematic diagram of the erosion apparatus. 

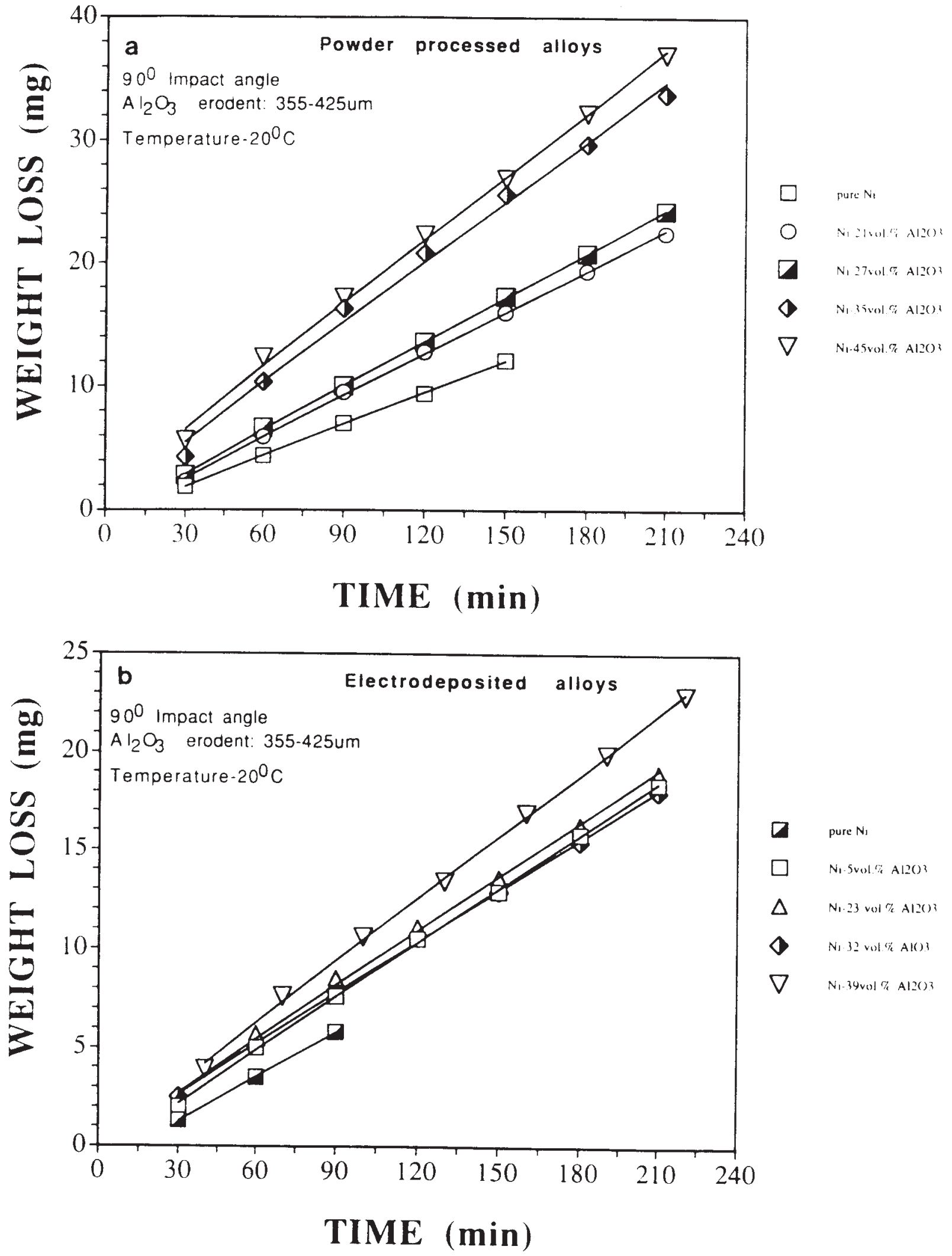

Figure $2 \mathbf{a}$ and $\mathbf{b}$. Erosion kinetics for the powder processed (a) and electrodeposited (b) $\mathrm{Ni}-\mathrm{Al}_{2} \mathrm{O}_{3}$ composite alloys. 


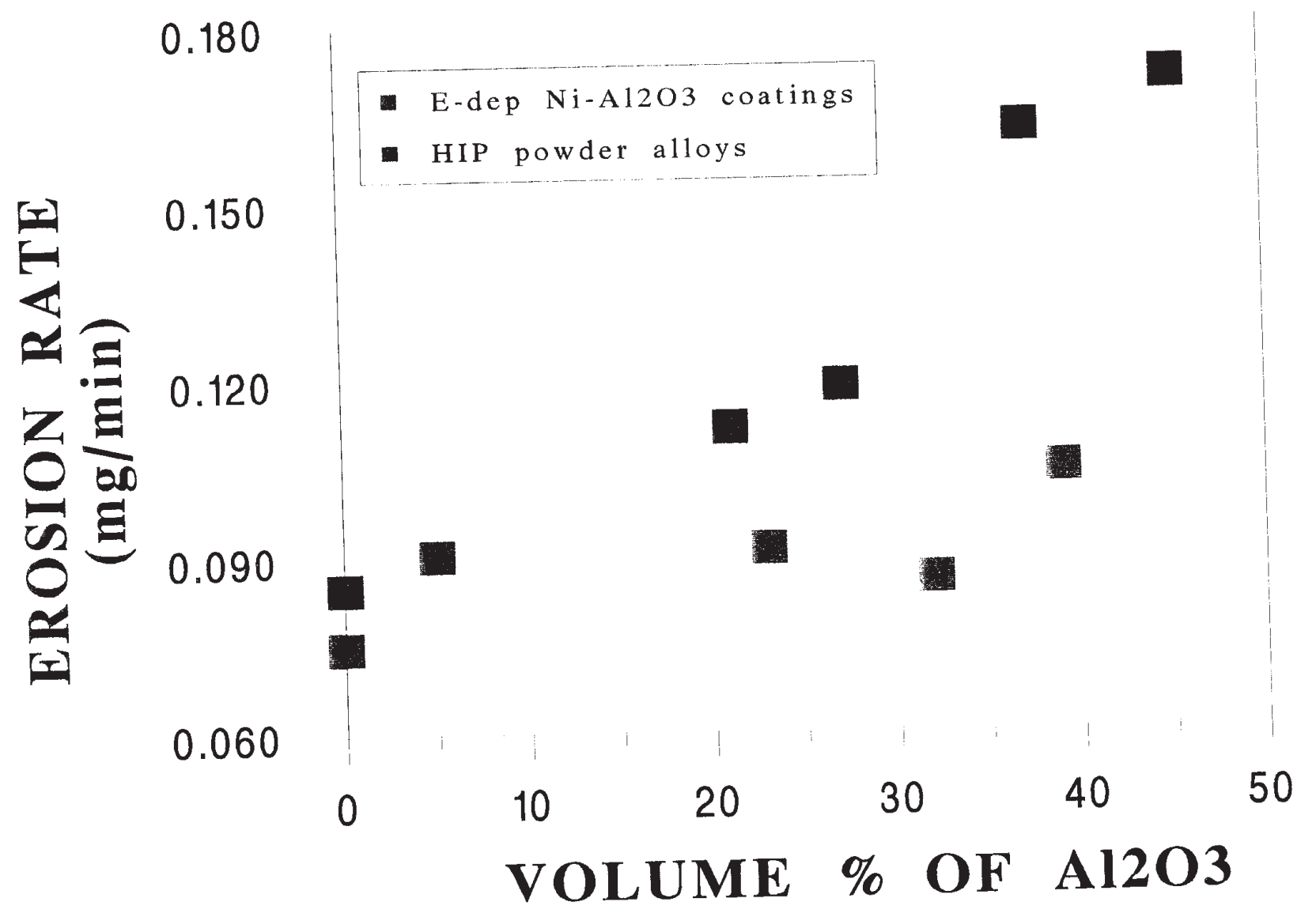

Figure 3. Effect of volume fraction of $\mathrm{Al}_{2} \mathrm{O}_{3}$ particles on erosion resistance of $\mathrm{Ni}-\mathrm{Al}_{2} \mathrm{O}_{3}$ composite alloys. 